УДК 378.016: [373. 5.011.3-051: 615.8]

DOI: $\underline{10.35619 / \text { iiu.v1i12.323 }}$

Чепурка Олег

Здобувач $\mathrm{PhD}$

кафедри теорії і методики виховання

Рівненського державного гуманітарного університету

ORCID: 0000-0002-3164-4832

e-mail: o.chepurka@gmail.com

\title{
СУТНІСТЬ ПОНЯТТЯ «ПРОФЕСІЙНА ПІДГОТОВКА МАЙБУТНІХ ФАХІВЦІВ 3 ФІЗИЧНОЇ РЕАБІЛІТАЦЇ̈» В КОНТЕКСТІ СУЧАСНОЇ ОСВІТНЬОЇ ПАРАДИГМИ
}

\begin{abstract}
Анотація. В статті обгрунтовано доцільність започаткування в закладах вищої освіти країни нової спеціальності «227 Фізична терапія, ерготерапія», метою освітньо-професійної програми якої є підготовка висококваліфікованого, конкурентоспроможного, інтегрованого в європейський та світовий науковоосвітній простір фахівця з фізичної реабілітації, який може кваліфіковано здійснювати виховну, фізкультурно-оздоровчу, реабілітаційну діяльність 3 різним контингентом населення, а також сприяти гармонійному розвитку особистості, формуванню життєво-необхідних навичок, розвитку фізичних якостей, зміцненню здоров'я, підготовці до активної трудової діяльності людини з обмеженими можливостями здоров'я.

Здійснено аналіз наукових праць сучасних учених з проблеми професійної підготовки майбутніх фахівців 3 фізичної реабілітації; 3'ясовано сутнісне наповнення базових понять підготовки майбутніх фахівців 3 фізичної реабілітації у контексті сучасної освітньої парадигми. Відповідно до мети і завдань освітньо-професійної програми «Фізична терапія» схарактеризовано поняття «фізична терапія», «фізична реабілітація», «професійна підготовка», «майбутні фахівці з фізичної реабілітації», «професійна підготовка майбутніх фахівців з фізичної реабілітації».

В результаті здійсненого аналізу професійну підготовку майбутніх фахівців 3 фізичної реабілітації визначено як різновекторний процес, що відповідає меті, принципам і завданням професійно-педагогічної діяльності та спрямовується на реалізацію відповідних іiі компонентів; відображає розвиток особистісних якостей майбутнього фахівця і результат оволодіння професійно орієнтованими знаннями, вміннями та навичками, які дають йому змогу спрямовувати свої зусилля на відновлення здоров'я людини, підвищення іiі працездатності та покращення функціонального стану організму.

Ключові слова. фізична терапія, фізична реабілітація, професійна підготовка, майбутні фахівці з фізичної реабілітації, професійна підготовка майбутніх фахівців з фізичної реабілітації.
\end{abstract}

Постановка проблеми. Соціально-економічна, екологічна й демографічна ситуації в Україні, як і в більшості країн світу, зумовили суттєве погіршення стану здоров'я всіх груп населення, особливо дітей, підлітків та молоді. Більше того, упродовж останніх десятиліть втрачена профілактична спрямованість охорони здоров'я та відсутні реальні важелі, що забезпечують формування

(C) Чепурка О., 2020 
відповідального ставлення людини до власного здоров'я. 3'явилася і поширюється тимчасова незайнятість населення, стан здоров'я став чинником профвідбору й профнепридатності. Населення країни в рази скоротило кількість звернень за медичною допомогою, особливо тепер, в умовах карантинних обмежень, зумовлених пандемією COVID 19.

У результаті значна кількість патологічних станів продовжує розвиватись, що само собою призводить до збільшення хронічних захворювань, інвалідності й передчасної смерті працездатного населення. Тому на сучасному етапі розвитку медицини все більше стверджується реабілітаційний напрям, головним завданням якого є поетапне, комплексне відновлення здоров'я людини. Значна роль у цьому процесі належить фізичній реабілітації. Вона поліпшує якість лікування, запобігає можливим ускладненням при різних захворюваннях i травмах, прискорює відновлення функцій органів і систем, тренує і загартовує організм, повертає працездатність, зменшує ймовірність інвалідності. А особам 3 особливими потребами фізична реабілітація допомагає розвинути навички самообслуговування, виробити постійні компенсації при незворотних змінах, пристосування до життя у нових умовах, що виникли внаслідок хвороби або травми (Мухін, 2000, с. 3).

Відповідно, в таких умовах логічно виникла необхідність започаткування в закладах вищої освіти (ЗВО) країни нової спеціальності «227 Фізична терапія, ерготерапія», метою освітньо-професійної програми якої $\epsilon$ підготовка висококваліфікованого, конкурентоспроможного, інтегрованого в європейський та світовий науково-освітній простір фахівця з фізичної реабілітації, який може кваліфіковано здійснювати виховну, фізкультурно-оздоровчу, реабілітаційну діяльність 3 різним контингентом населення, а також сприяти гармонійному розвитку особистості, формуванню життєво-необхідних навичок, розвитку фізичних якостей, зміцненню здоров'я, підготовці до активної трудової діяльності людини з обмеженими можливостями здоров'я (Освітньо-професійна програма «Фізична терапія»).

Аналіз останніх досліджень 3 проблеми. Окремі аспекти професійної підготовки фахівців з фізичної реабілітації в останні роки активно вивчаються українськими вченими. Приміром, аналіз понятійно-категоріального апарату здійснений Г. Верич, О. Дубогай (2003) та ін.; особливості підготовки фахівців 3 фізичної реабілітації у ЗВО досліджували В. Завацький, В. Кукса. (2001), Л. Сущенко й ін; специфіку діяльності фізичного реабілітолога вивчали А.Вовканич, В. Мухін (2000) та ін.; специфіку професійної підготовки майбутніх фахівців з фізичної реабілітації вивчали Л. Волошко (2005), В. Григоренко, В. Кукса, Ю. Лянний, О. Міхеєнко, В. Мурза, Л. Сущенко та ін.

Метою статті $\epsilon$ розкриття сутності поняття «професійна підготовка майбутніх фахівців з фізичної реабілітації» в контексті сучасної освітньої парадигми.

Виклад основного матеріалу дослідження. У контексті сучасних запитів й суспільних вимог до професійної підготовки майбутніх фахівців 3 фізичної реабілітації фізична терапія (англ.: Physical therapy) розглядається як застосування 3 лікувальною $\mathrm{i}$ профілактичною метою фізичних вправ i природних чинників у комплексному процесі відновлення здоров'я, фізичного стану та працездатності хворих. Своєю чергою, за визначенням комітету експертів Всесвітньої організації охорони здоров'я (ВООЗ), «фізична реабілітація - це активний процес, метою якого $\epsilon$ досягнення повного 
відновлення порушених внаслідок захворювання або травми функцій, або, якщо це нереально, оптимальна реалізація фізичного, психічного i соціального потенціалу інваліда, найбільш адекватна інтеграція його у суспільство» (Фізична реабілітація).

В сучасній науці поняття «фізична реабілітація» розглядається як процес, що має на меті забезпечити неповносправним досягнення i підтримку їх оптимальних фізичного, чуттєвого, інтелектуального, психічного, а також соціального рівнів діяльності, які б сприяли досягненню вищого рівня самостійності. Реабілітація може включати заходи для підтримання або відновлення функцій чи компенсації втрати або відсутності функції чи функціонального обмеження. Реабілітаційний процес починається буквально від першої медичної допомоги. Він охоплює широке коло заходів і видів діяльності, починаючи від основної та загальної реабілітації і до дій, спрямованих на досягнення кінцевої мети, наприклад, професійної реабілітації (Актуальні проблеми теорії і методики фізичного виховання, 2005).

Відповідно, у контексті такого тлумачення в Україні здійснюється підготовка фахівців з фізичної реабілітації. М. Герцик та О. Вацеба зазначають, що в Україні спеціальність «Фізична реабілітація» пройшла первинне формування у середині 90-х років минулого століття. Частково це відбулося як результат розширення контактів і обміну досвідом із органами охорони здоров'я зарубіжних країн. Зазначені автори вказують на те, що неабиякою базою розвитку фізичної реабілітації був чималий досвід використання лікувальної фізичної культури, нагромаджений у країнах пострадянського простору ще 3 часів Другої світової війни (Герцик та Вацеба, 2005, с. 95).

Фахівці 3 фізичної реабілітації надають послуги приватним особам та населенню загалом, метою яких $\epsilon$ максимально можливий розвиток, підтримання та відновлення втрачених або послаблених рухових функцій та працездатності організму впродовж усього життя. Відповідно, вони мають набути відповідної кваліфікації для виконання наступних професійних обов'язків:

проведення комплексного обстеження, оцінки та визначення необхідного рівня втручання для відновлення здоров'я окремого пацієнта або потреб групи пацієнтів;

встановлення діагнозу, визначення прогнозів і плану заходів;

надання консультації у межах своєї компетенції та визначення того, коли пацієнтам необхідно звернутися до інших медичних фахівців;

впровадження програми реабілітації чи лікування, складеної фізичним терапевтом;

визначення очікуваних результатів будь-якого реабілітації чи лікування;

надання рекомендацій пацієнту чи групі пацієнтів для самостійного виконання ними завдань (програми реабілітації) (Фізична реабілітація).

Г. Верич вважає, що фізична реабілітація - це комплекс послуг, які надаються виключно фахівцем 3 фізичної реабілітації або під його керівництвом і контролем. Вона включає в себе обстеження, вивчення, оцінку, діагностування, прогнозування, планування догляду чи безпосереднє втручання та повторне обстеження (2003, с. 13-14].

Поняття «підготовка» в «Енциклопедії професійної освіти» тлумачиться як «загальний термін стосовно прикладних завдань освіти, коли передбачається засвоєння певного соціального досвіду з метою його подальшого застосування 
під час виконання специфічних завдань практичного, пізнавального чи навчального характеру» (Энциклопедия професионального образования, 1999, c. 234). А в психологічному словнику поняття «підготовка» розглядається як «формування та збагачення настанов, знань та умінь, які необхідні індивіду для адекватного виконання специфічних завдань» (2007, с. 140). Своєю чергою, О. В. Бойченко поняттям «підготовка» маркує «процес, в якому формуються та вдосконалюються професійні знання, вміння, навички та особистісні якості, що необхідні в майбутній педагогічній діяльності» (2014, с. 79).

Цілком логічно, що й поняття «професійна підготовка» має різні тлумачення. У Законі України «Про вищу освіту» (2014) під поняттям «професійна підготовка» розуміється «процес здобуття кваліфікації за відповідним напрямом підготовки або спеціальністю» (Зайченко, 2008). У «Термінологічному словнику 3 основ підготовки наукових та науковопедагогічних кадрів післядипломної педагогічної освіти» поняття «професійна підготовка» тлумачиться як «система професійного навчання, що має за мету придбання професійних навичок, необхідних для виконання певної роботи, що супроводжується підвищенням освітнього рівня знань» (2014, с. 139). А в «Енциклопедії професійної освіти» «професійна підготовка» трактується як сукупність спеціальних знань, умінь і навичок, якостей трудового досвіду і норм поведінки, що забезпечують можливість успішної роботи з визначеної професії (Энциклопедия професионального образования, 1999).

В «Українському педагогічному словнику» С. Гончаренко професійну підготовку трактував як: «1) підготовку в навчальних закладах фахівців різних рівнів кваліфікації для трудової діяльності в одній із галузей народного господарства, науки, культури; 2) невід'ємну складову частину єдиної системи народної освіти; 3) сукупність знань, навичок і умінь, оволодіння якими дозволяє працювати фахівцем вищої, середньої кваліфікації або кваліфікованим робітником» (1997, с. 274-275). Тобто, професійна підготовка - це система організаційних i педагогічних заходів, що забезпечують формування в особистості професійної спрямованості знань, умінь, навичок і професійної готовності.

У контексті сучасної освітньої парадигми А. Фастівець вважає, що майбутній фахівец̧ь 3 фізичної реабілітації - це «особистість, що цілеспрямовано здобуває кваліфікацію відповідно до обраного освітньокваліфікаційного рівня в процесі спеціально організованої навчально-виховної діяльності у вищому навчальному закладі, спрямованої на формування високої якості реабілітаційної культури та культури здоров'язбереження на основі діагностичної компетентності» (2016, с. 78).

Відповідно, О. Бойченко у контексті сучасної освітньої парадигми вважає, що професійна підготовка майбутнього фахівця здійснюється «до такої організації навчально-виховного процесу, під час якої студент набуває професійних якостей, тому особлива увага викладачів вищого навчального закладу повинна бути зосереджена на розвиток потенціалу, формування стійкої мотивації і готовності кожного студента до саморозвитку, самоактуалізації і самоуправління» $(2014$, с. 80$)$.

При цьому О. Карпухіна стверджує, що «фізична реабілітація суттєво відрізняється від інших спеціальностей вищої професійної освіти». Майбутній фахівець 3 фізичної реабілітації, на думку дослідниці, «має широко 
орієнтуватися у професійній сфері, бачити перспективи ії подальшого розвитку і вдосконалення» (2010, с. 65-69).

Своєю чергою, професійну підготовку фахівця з фізичної культури і спорту О. Скріплєва й Т. Скоблікова вважають «складною, динамічною педагогічною системою, ефективність функціонування якої залежить від безлічі чинників, що проявляються на основі загальних закономірностей педагогічного процесу й управління ним» (2008). Основним завданням цієї системи є підготовка висококваліфікованих фахівців для всіх ланок галузі на основі реального попиту на їхні послуги.

Відповідно, Л. Сущенко під професійною підготовкою майбутніх фахівців 3 фізичної реабілітації розуміє процес, який відображає науково й методично обгрунтовані заходи закладів вищої освіти, спрямовані на формування протягом певного терміну навчання рівня професійної компетентності особистості, достатнього для проведення фізичної реабілітації різних верств населення регіону й успішної праці в лікувально-профілактичних закладах з урахуванням сучасних вимог ринку праці (2007).

Тобто, професійна підготовка майбутніх фахівців з фізичної реабілітації - це спеціально організований процес професійного розвитку фахівця, спрямований на формування впродовж терміну навчання у закладі вищої освіти такого рівня професійної компетентності особистості, який буде достатнім для виконання майбутніх професійних завдань.

В результаті здійсненого аналізу професійну підготовку майбутніх фахівців з фізичної реабілітації визначаємо як різновекторний процес, що відповідає меті, принципам i завданням професійно-педагогічної діяльності та спрямовується на реалізацію відповідних пї компонентів; відображає розвиток особистісних якостей майбутнього фахівця і результат оволодіння професійно орієнтованими знаннями, вміннями та навичками, які дають йому змогу спрямовувати свої зусилля на відновлення здоров’я людини, підвищення іiі працездатності та покращення функціонального стану організму.

Висновки і перспективи подальших розвідок. Таким чином, на основі здійсненого аналізу можна зробити висновок про те, що визначення сутності поняття «професійна підготовка майбутніх фахівців 3 фізичної реабілітації» в контексті сучасної освітньої парадигми як спеціально організованого процесу професійного розвитку фахівця, спрямованого на формування впродовж терміну навчання у закладі вищої освіти такого рівня професійної компетентності особистості, який буде достатнім для виконання майбутніх професійних завдань дає змогу забезпечити якісну підготовку висококваліфікованих фахівців 3 фізичної реабілітації, якісний педагогічний супровід засвоєння здобувачами вищої освіти освітньо-професійної програми «Фізична терапія».

Перспективи подальших розвідок вбачаємо у вивченні й узагальненні зарубіжного досвіду підготовки майбутніх фахівців з фізичної реабілітації та окресленні можливостей застосування кращих зарубіжних практик у системі професійної підготовки майбутніх фахівців з фізичної реабілітації у вітчизняних закладах вищої освіти; у вивченні професійної підготовки майбутніх фахівців 3 фізичної реабілітації у процесі дуальної освіти. 


\section{СПИСОК ВИКОРИСТАНИХ ДЖЕРЕЛ}

Мухін, В. (2000). Фізична реабілітація: Підручник для студентів вищих навчальних закладів фізичного виховання i спорту. Київ: Олімпійська література, $423 \mathrm{c}$.

Освітньо-професійна програма «Фізична терапія». URL: https://www.rshu.edu.ua/images/osvitni_programi/osv_prog_bak_227_fiz_terapi_ergo ter_2020.pdf [Дата останнього звернення 5 жовтня 2020].

Верич, Г. и Бородин, Ю. (2003). Проблема, итоги и перспективы преподавания специальности «физическая реабилитация» в вузах. В: Фізична реабілітація як напрям підготовки спеціалістів. Київ, с. 13-14.

Кукса, В. (2001). Сутність фізичної реабілітації. Теорія і методика фізичного виховання і спорту. № 1. С. 46-51.

Волошко, Л. (2005). Організаційно-педагогічні умови формування професійної компетентності майбутніх фахівців 3 фізичної реабілітації в процесі медико-біологічної підготовки. Педагогіка, психологія та медико-біологічні проблеми фізичного виховання і спорту. №24. С. 42-44.

Фізична реабілітація.

URL: https://uk.wikipedia.org/wiki/\%D0\%A4\%D1\%96\%D0\%B7\%D0\%B8\%D1\%87\%D0\% BD\%D0\%B0_\%D1\%80\%D0\%B5\%D0\%B0\%D0\%B1\%D1\%96\%D0\%BB\%D1\%96 $\% \mathrm{D} 1 \% 82 \% \mathrm{D} 0 \% \mathrm{~B} 0 \% \mathrm{D} 1 \% 86 \% \mathrm{D} 1 \% 96 \% \mathrm{D} 1 \% 8 \mathrm{~F}$ [Дата останнього звернення 7 жовтня 2020].

Актуальні проблеми теорії $i$ методики фізичного виховання. (2005). Колективна монографія / Упоряд. О. М. Вацеба, Ю. В. Петришин, Є. Н. Приступа, І. Р. Боднар. Л., Українські технології, 296 с.

Герцик, М. і Вацеба, О. (2005). Вступ до спечіальностей галузі «фізичне виховання і спорт». Харків : «ОВС», $240 \mathrm{c}$.

Эничиклопедия профессионального образования. (1999). В 3 т. / под ред. С. Я. Батышева. Москва: АПО, Т. 2. 390 с.

Психологічний словник. (2007). авт.-уклад.: В. В. Синявський, О. П. Сергєєнкова ; за ред. Н. А. Побірченко. Київ: Наук, світ, 274 с.

Бойченко, О. В. (2014). Сутність поняття «підготовка майбутніх учителів фізико-математичних дисциплін» на сучасному етапі. Наука $i$ oсвіта. № 1. С. 79-82.

Зайченко, І. В. (2008). Педагогіка. 2-ге вид. Київ: Освіта України, 528 с.

Термінологічний словник з основ підготовки наукових та науковопедагогічних кадрів післядипломної педагогічної освіти. (2014). Авт. кол.: Є. Р. Чернишова, Н. В. Гузій, В. П. Ляхоцький [та ін.]; за наук, ред. С. Р. Чернишової. Київ: ДВНЗ «Університет менеджменту освіти», 230 с.

Гончаренко, С. (1997). Український педагогічний словник. Київ: Либідь, $376 \mathrm{c}$.

Фастівець, А. (2016). Професійна підготовки майбутніх фахівців $з$ фізичної реабілітації у вітчизняній і зарубіжній педагогіці. Педагогічні науки. № 66-67. с. 77-82.

Карпухіна, О. (2010). Проблеми підготовки фахівців з фізичної реабілітації. В: Проблеми фізичного здоров'я фахівия XXI століття. Кіровоград: Кіровоград. ін-т розвитку людини «Україна», С. 65-69.

Скриплева, Е. и Скобликова, Т. Профессиональная подготовка специалистов по физической культуре в современных условиях. Ученые записки. 
URL : http:// scientific-notes.ru/index.php?page=6\&new=7 [Дата последнего обращения 6 октября 2020]

Сущенко, Л. (2007). Формування мотивації до успішної професійної діяльності майбутніх фахівців із фізичної реабілітації. Педагогіка, психологія та медико-біологічні проблеми фізичного виховання і спорту. 2007. №6. С. 276-279.

\section{REFERENCES}

Mukhin, V. (200). Fizychna reabilitatsiia: [Physical rehabilitation]. Pidruchnyk dlia studentiv vyshchykh navchalnykh zakladiv fizychnoho vykhovannia i sportu. Kyiv: Olimpiiska literatura, 423 s. [in Ukrainian]

Osvitno-profesiina prohrama "Fizychna terapiia" [Educational and professional program "Physical Therapy"]. URL: https:// www. rshu.edu.ua/images/osvitni_programi/osv_prog_bak_227_fiz_terapi_ergoter_2020.pdf [Data ostannoho zvernennia 5 zhovtnia 2020]. [in Ukrainian]

Verych, H. i Borodin, Yu. (2003). Problema, itohi i perspektyvy prepodavaniya spetsialnosti "fizicheskaya reabylytatsiya» $\mathrm{v}$ vuzakh. [The problem, results and prospects of teaching the specialty "physical rehabilitation" in universities]. V: Fizychna reabilitatsiia yak napriam pidhotovky spetsialistiv. Kyiv, s. 13-14. [in Ukrainian]

Kuksa, V. O. (2001). Sutnist fizychnoi reabilitatsii [The essence of physical rehabilitation]. Teoriia i metodyka fizychnoho vykhovannia i sportu. № 1. S. 46-51. [in Ukrainian]

Voloshko, L. B. (2005). Orhanizatsiino-pedahohichni umovy formuvannia profesiinoi kompetentnosti maibutnikh fakhivtsiv z fizychnoi reabilitatsii $\mathrm{v}$ protsesi medyko-biolohichnoi pidhotovky [Organizational and pedagogical conditions for the formation of professional competence of future specialists in physical rehabilitation in the process of medical and biological training]. Pedahohika, psykholohiia ta medykobiolohichni problemy fizychnoho vykhovannia $i$ sportu. No 24. S. 42-44. [in Ukrainian]

Fizychna reabilitatsiia [Physical rehabilitation]. URL: https:// uk.wikipedia.org/wiki/\%D0\%A4\%D1\%96\%D0\%B7\%D0\%B8\%D1\%87\%D0\%BD\% D0\%B0_\%D1\%80\%D0\%B5\%D0\%B0\%D0\%B1\%D1\%96\%D0\%BB\%D1\%96\%D1\% $82 \% \mathrm{D} 0 \% \mathrm{~B} 0 \% \mathrm{D} 1 \% 86 \% \mathrm{D} 1 \% 96 \% \mathrm{D} 1 \% 8 \mathrm{~F}$ [Data ostannoho zvernennia 7 zhovtnia 2020]. [in Ukrainian]

Aktualni problemy teorii i metodyky fizychnoho vykhovannia [Actual problems of the theory and methods of physical education]. (2005). Kolektyvna monohrafiia / Uporiad. O. M. Vatseba, Yu. V. Petryshyn, Ye. N. Prystupa, I. R. Bodnar. L., Ukrainski tekhnolohii, 296 s. [in Ukrainian]

Hertsyk, M. i Vatseba, O. (2005). Vstup do spetsialnostei haluzi "fizychne vykhovannia i sport"[Introduction to the specialties of "physical education and sports"]. Kharkiv : "OVS", 240 s. [in Ukrainian]

Entsyklopediya professionalnogo obrazovaniya [Encyclopedia of vocational education]. (1999). V 3 t. / pod red. S. Ya. Batysheva. Moskva: APO, T. 2. 390 s. [in Russian]

Psykholohichnyi slovnyk [Psychological dictionary]. (2007). avt.-uklad.: V. V. Syniavskyi, O. P. Serhieienkova ; za red. N. A. Pobirchenko. Kyiv: Nauk, svit, 274 s. [in Ukrainian]

Boichenko, O. (2014). Sutnist poniattia "pidhotovka maibutnikh uchyteliv fizykomatematychnykh dystsyplin" na suchasnomu etapi [The essence of the concept of 
"training of future teachers of physical and mathematical disciplines" at the present stage]. Nauka i osvita. No 1. S. 79-82. [in Ukrainian]

Zaichenko, I. V. (2008). Pedahohika [Pedagogy]. 2-he vyd. Kyiv: Osvita Ukrainy, 528 s. [in Ukrainian]

Terminolohichnyi slovnyk z osnov pidhotovky naukovykh ta naukovopedahohichnykh kadriv pisliadyplomnoi pedahohichnoi osvity [Terminological dictionary on the basics of training scientific and scientific-pedagogical staff of postgraduate pedagogical education]. (2014). Avt. kol.: Ye. R. Chernyshova, N. V. Huzii, V. P. Liakhotskyi [ta in.]; za nauk, red. Ye. R. Chernyshovoi. Kyiv: DVNZ "Universytet menedzhmentu osvity", 230 s. [in Ukrainian]

Honcharenko, S. (1997). Ukrainskyi pedahohichnyi slovnyk [Ukrainian pedagogical dictionary]. Kyiv: Lybid, 376 s. [in Ukrainian]

Fastivets, A. (2016). Profesiina pidhotovky maibutnikh fakhivtsiv z fizychnoi reabilitatsii u vitchyznianii i zarubizhnii pedahohitsi [Professional training of future specialists in physical rehabilitation in domestic and foreign pedagogy]. Pedahohichni nauky. No 66-67. s. 77-82. [in Ukrainian]

Karpukhina, O. V. (2010). Problemy pidhotovky fakhivtsiv z fizychnoi reabilitatsii [Problems of training specialists in physical rehabilitation].V: Problemy fizychnoho zdorovia fakhivtsia XXI stolittia. Kirovohrad: Kirovohrad. in-t rozvytku liudyny «Ukraina», S. 65-69. [in Ukrainian]

Skrypleva, E. y Skoblykova, T. (2008). Professionalnaya podgotovka spetsyalistov po fizicheskoi kulture v sovremennykh usloviyakh. [Professional training of specialists in physical culture in modern conditions.Uchenye zapiski]. URL : http:// scientific-notes.ru/index.php?page $=6 \&$ new $=7$ [Data posledneho obrashcheniya 6 oktiabria 2020] [in Russian]

Sushchenko, L. P. (2007). Formuvannia motyvatsii do uspishnoi profesiinoi diialnosti maibutnikh fakhivtsiv iz fizychnoi reabilitatsii [Formation of motivation for successful professional activity of future specialists in physical rehabilitation]. Pedahohika, psykholohiia ta medyko-biolohichni problemy fizychnoho vykhovannia $i$ sportu. 2007. No 6. S. 276-279. [in Ukrainian]

\title{
THE ESSENCE OF THE CONCEPT "PROFESSINAL TRAINING OF FUTURE SPECIALISTS IN PHYSICAL THERAPY” IN THE CONTEXT OF THE MODERN EDUCATIONAL PARADIGM
}

\author{
Oleg Chepurka \\ $\mathrm{PhD}$ applicant \\ Department of Theory and Methods of Education, \\ Rivne State University for the Humanities \\ Rivne, Ukraine \\ ORCID: 0000-0002-3164-4832 \\ e-mail: o.chepurka@gmail.com
}

\begin{abstract}
The article substantiates the expediency of starting a new specialty " 227 Physical therapy. Occupational therapy" in state establishments of higher education. The aim of the curriculum is training of highly qualified competitive physiotherapy specialist, integrated into European and global spheres of science and education, capable to carry out qualified educational, physical cultural, health rehabilitation activities with different contingent of the population, to provide harmonious
\end{abstract}


development of a personality, vital skills formation, physical qualities development, health promotion, preparation to active work of disabled people.

The article presents the analysis of modern scientists' research on the problem of professional training of future specialists in physical therapy. The essence of basic concepts of future specialists in physical therapy training in the context of modern educational paradigm is defined. In the accordance with the purpose and objectives of the educational-professional program "Physical therapy" the notions "physical therapy", "physical rehabilitation", "professional training", "future specialists in physical therapy", "professional training of future specialists in physical therapy" are characterized.

As a result of the analysis the author defines professional training of future specialists in physical therapy as a multi-vector process that meets the goal, principles and tasks of professional and pedagogical activity and is aimed at implementing its appropriate component. It reflects the development of personal qualities of future specialist and the result of acquired professional knowledge, skills and abilities which give the possibility to focus efforts of the specialist on restoring human health, increasing efficiency and improving functional body state.

Key words: physical therapy, physical rehabilitation, professional training, future specialists in physical therapy, professional training of future specialists in physical therapy.

Стаття надійшла до редакиії 09. 10. 2020 р. 